\title{
RESPON PETANI TERHADAP PELAKSANAAN DISPLAI PADI GOGO VUB PADA LAHAN SUB OPTIMAL DI SULAWESI SELATAN
}

\section{Farmers Response on VUB “Gogo" Rice Display on Sub-Optimal Land in South Sulawesi}

\author{
Sunanto* dan Abd. Wahid Rauf \\ Balai Pengkajian Teknologi Pertanian (BPTP) Sulawesi Selatan \\ *Kontak penulis: sunanto_bptpsulsel@yahoo.co.id
}

\begin{abstract}
The Gogo rice is a food crop that contributes to food self-sufficiency. Food demand, especially rice continues to increase along with population growth. Because of the higher food needs and the narrowness of fertile land, due to the land conversion function. So the utilization of sub-optimal lands / landed with appropriate food crops. The potency of the sub-optimal area in South Sulawesi is 274,549 hectares. The purpose of this research is to know how sub-optimal land used and farmer appraisal to gogo rice. This research was conducted in Wajo and Jeneponto Regencies from January to December 2017. The research used survey method and display of gogo rice plant NSV of Agricultural Research Agency in the field. The number of farmers taken as a sample of 80 farmers. The technique of collecting data by interview method and observation of vegetative and generations of display gogo rice plant. The collected data are then tabulated and then analyzed descriptively and test the agreement and business feasibility. The activities of rice farming on sub-optimal land are done by farmers that have the productive age. The application of rice farming technology to suboptimal land has not been intensive yet. Display gogo rice plant VUB resulted from Agricultural Research Agency appropriate to be planted with / out sub-optimal land of dry land and irrigated rice fields limited. Understanding farmers on superior gogo rice are not optimal $(77.50 \%)$. Farmer's preference to superior gogo farmers. Rice farming of farmers provides income (implicative). Rp 4.575.000/ha, (explicit). Rp 7.245.000/ha and R/C (implicative ) 1.62 and (explicit ) 2.53 .
\end{abstract}

Keywords: upland rice; VUB; land; sub optimal.

Sitasi: Sunanto dan A.W. Rauf, 2018. Respon Petani Terhadap Pelaksanaan Displai Padi Gogo VUB pada Lahan Sub Optimal di Sulawesi Selatan, JSEP 14(2): 143 - 160.

\section{Pendahuluan}

Padi gogo merupakan komoditas tanaman pangan yang turut mendukung swasembada pangan. Komoditas padi tersebut sangat penting di Indonesia. Penduduk Indonesia menjadikan beras sebagai bahan makanan pokok. Sembilan puluh lima persen penduduk Indonesia mengkonsumsi bahan makanan ini. Beras mampu mencukupi $63 \%$ total kecukupan energi dan $37 \%$ protein. Sedangkan kandungan protein beras berkisar 6,9\% - 8,7\% dan kandungan gula mencapai 0,14\% 0,09\% (Hernawan dan Meylani, 2016).

Kebutuhan pangan, khususnya beras terus meningkat seiring dengan pertumbuhan jumlah penduduk. Laju pertumbuhan penduduk mencapai 0,37\%, hal tersebut mengakibatkan permasalahan pendidikan, kesehatan, kemiskinan, kepadatan penduduk (Christiani et al., 2012). Pertumbuhan penduduk ini akan mampu menggeser fungsi lahan pertanian ke sektor yang lain. 
Lahan sub optimal dapat diartikan sebagai lahan yang secara alamiah mempunyai produktivitas rendah disebabkan oleh faktor internal (instrinsik) seperti bahan induk, sifat fisik, kimia dan biologi tanah dan faktor eksternal seperti curah hujan dan suhu ekstrim (Las et al., 2012; Mulyani dan Sarwani, 2013). Karena semakin tingginya kebutuhan pangan dan semakin sempitnya lahan subur akibat alih fungsi lahan, maka perlu adanya pemanfaatan lahan sub optimal dengan komoditas tanaman pangan yang sesuai.

Potensi lahan sawah Sulawesi Selatan mencapai 642.506 ha dan 274.549 ha diantaranya masuk kategori lahan sub optimal. Beberapa faktor teknis dan nonteknis yang menjadi kendala dalam pemanfaatan lahan pertanian di masa yang akan datang seperti menurunnya kapasitas dan kualitas infrastruktur, konversi lahan, degradasi lahan dan air, perubahan iklim, kerusakan lingkungan, kesenjangan hasil antara di tingkat penelitian dan di petani, kurang menariknya kegiatan pertanian bagi generasi muda, serta persaingan penggunaan lahan antara sektor pertanian dan non pertanian seperti infrastruktur, industri, perkotaan/pemukiman (Mulyani et al., 2011).

Strategi nasional untuk menghadapi tantangan tersebut adalah: 1) menghindari kompetisi penyediaan pangan untuk ketahanan pangan dengan memprioritaskan penggunaan komoditas bioenergi non pangan untuk bioenergi, dan 2) menghindari kompetisi penggunaan lahan untuk pangan melalui pemanfaatan lahan sub optimal bagi komoditas non pangan (Las dan Mulyani 2009). Sebagian lahan yang tersisa untuk pengembangan pertanian ke depan adalah lahan sub optimal atau marginal (tadah hujan, lahan kering masam, dan lahan rawa) dengan berbagai masalah biofisik (Mulyani et al., 2011).

Luas lahan kering di Sulawesi Selatan tahun 2013 sebesar 274.549 ha dengan produktivitas padi gogo sebesar 2,56 t/ha jauh lebih rendah dibandingkan dengan rata-rata produktivtas padi sawah yaitu sebesar 5,6 t/ ha (Distan Prov. Sulsel, 2014).

Pengembangan padi gogo diperlukan untuk memanfaatkan potensi lahan kering dan guna memenuhi kebutuhan pangan nasional. Petani merespon pada tanaman padi dilihat dari pertumbuhan vegetatif dan gereratifnya. Untuk uji organoleptik pada padi petani menyukai varietas Inpari 22 (Sunjaya dan Haryati, 2018). Oleh sebab itu pengujian respon petani terhadap padi gogo VUB hasil Badan Litbang Pertanian perlu dilakukan.

\section{Metode Penelitian}

Penelitian ini dilaksanakan di Kecamatan Gilireng Kabupaten Wajo dan Kecamatan Togo-Togo Kabupaten Jeneponto. Penentuan lokasi ini berdasarkan bahwa lokasi kegiatan terdapat lahan sub optimal dan dimanfaatkan dengan tanaman padi gogo. Sehingga untuk memperbaiki produktivitasnya, maka juga dilakukan displai padi gogo VUB Badan Litbang Pertanian.

Penelitian menggunakan metode survei dan displai tanaman padi VUB Badan Litbang Pertanian di lapangan. Metode pengambilan sampel pada survei dilakukan dengan menggunakan teknik Purposive Sampling, yaitu teknik sampling yang didasarkan pada pertimbangan dan kriteria tertentu berdasarkan tujuan penelitian, yaitu petani padi lahan sub optimal. Jumlah petani yang diambil sebagai sampel sebanyak 80 petani yaitu masing-masing 40 petani di Kabupaten Wajo dan Kabupaten Jeneponto. 
Untuk mengetahui respon petani terhadap padi VUB lahan sub optimal hasil Badan Litbang Pertanian, maka dilakukan verifikasi teknologi usahatani padi VUB pada lahan sub optimal. Luas plot verifikasi teknologi usahatani padi gogo seluas 0,5 ha. adapun pelaksanaan displai sebagai berikut, benih padi yang digunakan VUB Inpago yang tahan terhadap cekaman air. Benih sebelum ditanam dilakukan perendaman selama 24 jam. Kemudian ditiriskan. Penanaman benih padi Inpago secara langsung pada lahan sawah tadah hujan dengan cara menugal sistem jajar legowo. Pemeliharaan tanaman dilakukan dengan pemupukan dengan dosis $200 \mathrm{~kg}$ Urea, $150 \mathrm{~kg}$ NPK, $4.000 \mathrm{~kg}$ pukan per hektar. Adapun pengendalian hama penyakit dan gulma dilakukan secara intensif. Panen dilakukan setelah biji padi masak fisiologis.

Teknik yang dipergunakan untuk mengumpulkan data adalah metode wawancara dengan menggunakan alat bantu kuesioner yang disesuaikan dengan kebutuhan data dan informasi yang diperlukan. Data yang diperlukan adalah data primer tentang karakteristik petani, biaya serta penerimaan usahatani padi lahan sub optimal yang diperoleh secara langsung dari petani.

Metode analisis data yang digunakan pada penelitian ini diuraikan sebagai berikut:

a. Biaya usahatani dihitung dengan rumus (Soekartawi, 2006):

$$
T C=F C+V C
$$

Keterangan :

$\mathrm{TC}=$ Total biaya $(\mathrm{Rp})$,

$\mathrm{FC}=$ Jumlah biaya tetap (penyusutan, pajak tanah) (Rp) dan

VC = Jumlah biaya variabel (tenaga kerja keluarga, tenaga kerja luar, benih, pupuk, pestisida) (Rp).

b. Penerimaan usahatani menggunakan rumus (Soekartawi, 2006):

$$
T R=Y . P y
$$

Keterangan:

$\mathrm{TR}=$ Total penerimaan,

$\mathrm{Y}=$ Produksi yang diperoleh $(\mathrm{Kg})$ dan

Py $=$ Harga $Y(R p)$

c. Pendapatan usahatani dihitung dengan menggunakan rumus (Soekartawi, 2006):

Keterangan :

$$
P d=T R-T C
$$

$\mathrm{Pd}=$ Pendapatan usahatani $(\mathrm{Rp})$,

$\mathrm{TR}=$ Total penerimaan $(\mathrm{Rp})$ dan

$\mathrm{TC}=$ Total biaya mengusahakan $(\mathrm{Rp})$

d. Efisiensi usahatani menggunakan rumus:

Keterangan:

$$
R / C=T R / T C
$$

$\mathrm{R} / \mathrm{C}=$ Revenue cost ratio,

$\mathrm{TR}=$ Total revenue dan

$\mathrm{TC}=$ Total cost

Kriteria : Jika R/C $>1$, maka usahatani efisien,

Jika $\mathrm{R} / \mathrm{C}=1$, maka usahatani dalam keadaan impas (tidak rugi dan tidak untung) dan

Jika $\mathrm{R} / \mathrm{C}<1$, maka usahatani tidak efisien 
e. Analisis respon petani terhadap VUB padi lahan sub optimal menggunakan analisis uji kesepakatan konkordansi kendall's dengan rumus (Siegel, 1997) sebagai berikut:

$$
W=\frac{S}{1 / 12 . K\left(N^{2}-N\right)}
$$

$$
\begin{aligned}
\text { dimana }: \mathrm{W} & =\text { Tingkat kecocokan (kesepakatan) } \\
\mathrm{s} & =\text { Jumlah kuadrat deviasi observasi dari mean } \mathrm{R}_{\mathrm{i}}, \mathrm{s}=\sum\left(\mathrm{Ri}-\frac{\sum \mathrm{Ri}}{\mathrm{N}}\right)^{2} \\
\mathrm{k} & =\text { Banyak himpunan rangking perjenjangan (banyak penilai) } \\
\mathrm{N} & =\text { Banyaknya obyek atau individu yang diberi nilai }
\end{aligned}
$$

f. Untuk menguji signifikansi $W$ pada sampel-sampel besar menggunakan rumus distribusi chi-square dengan $\mathrm{db}=\mathrm{N}-1$, yaitu :

$$
X^{2}=k(N-1) W
$$

Kriteria pengambilan keputusan dengan menggunakan nilai $\mathrm{X}^{2}$ pada tingkat kepercayaan $95 \%$ :

1. Jika $X^{2}$ hit $\geq X^{2}$ tab, maka Ho ditolak, berarti ada kecocokan (kesepakatan) yang nyata dalam meranking kegiatan demplot pupuk organik diantara petani.

2. Jika $X^{2}$ hit $<X^{2}$ tab maka Ho diterima, berarti tidak ada kecocokan (kesepakatan) yang nyata dalam meranking kegiatan demplot pupuk organik diantara petani.

\section{Hasil dan Pembahasan}

\section{Karakteristik Petani}

Petani sebagai pelaksana usahatani padi pada lahan sub optimal memiliki karakteristik yang mempengaruhi cara dan pola usahatani padi. Identitas petani yang dikumpulkan meliputi umur, pendidikan, jumlah anggota keluarga, pengalaman dan penguasaan lahan.

Kelompok umur petani padi yang berada di wilayah Kabupaten Jeneponto dan Wajo, sebagian besar pada kelompok umur 36 - 45 tahun mencapai 28 petani $(35,00 \%)$, Kemudian diikuti pada kelompok umur 26 - 35 tahun sebanyak 19 petani $(23,75 \%)$, dan selebihnya kelompok umur 46 - 55 tahun sebanyak 17 petani $(21,25 \%)$. Hal ini tergambar pada data yang disajikan Tabel 1.

Berdasarkan data pada Tabel 1 menunjukkan kelompok usia petani padi pada kedua lokasi kegiatan termasuk dalam kategori usia produktif. Larsito (2005), melaporkan bahwa umur produktif yang bekerja di negara-negara berkembang pada umumnya adalah 15-55 tahun, artinya kemampuan untuk bekerja lebih baik dari usia lanjut dan anak-anak serta dalam berusahatani kemungkinan untuk meningkatkan hasil masih dapat ditingkatkan bila disertai kemampuan usaha. Hal tersebut sependapat dengan hasil penelitian Mardani et al (2017) bahwa petani jagung di Kabupaten Bireuen juga kelompok umur produktif mendominasi pada karakteristik petani. 
Tabel 1

Karaktersitik Umur Petani Padi pada Lahan Sub Optimal, 2017

\begin{tabular}{cccc}
\hline No. & $\begin{array}{c}\text { Kelompok Umur } \\
\text { (tahun) }\end{array}$ & $\begin{array}{c}\text { Jumlah } \\
\text { (petani) }\end{array}$ & $\begin{array}{c}\text { Persentase } \\
\text { (\%) }\end{array}$ \\
\hline 1. & $\leq 25$ & 3 & 3,75 \\
2. & $26-35$ & 19 & 23,75 \\
3. & $36-45$ & 28 & 35,00 \\
4. & $46-55$ & 17 & 21,25 \\
5. & $\geq 56$ & 13 & 16,25 \\
\hline & Jumlah & $\mathbf{8 0}$ & $\mathbf{1 0 0 , 0 0}$ \\
\hline
\end{tabular}

Tingkat pendidikan mempengaruhi upaya dalam peningkatan pengetahuan dan keterampilan petani. Sebagian besar petani masih memiliki tingkat pendidikan yang rendah, yaitu setara lulus di bawah sekolah dasar. Sedangkan petani yang memiliki pendidikan lebih dari sepuluh tahun mencapai 19 petani (23,75\%). Selanjutnya yang lulus setara sekolah menengah pertama adalah 16 petani $(20,00 \%)$. Hal ini sejalan dengan Budiartiningsing et al. (2010), bahwa pendidikan pada kegiatan usahatani sebagaian besar berpendidikan dasar. Hal tersebut juga diungkapkan oleh Susanti et al (2016), bahwa tingkat pendidikan berpengaruh positif terhadap peningkatan produksi usahatani. Karakteristik tingkat pendidikan petani padi pada lahan sub optimal di lokasi penelitian diuraikan pada Tabel 2.

Tabel 2

Karaktersitik Tingkat Pendidikan Petani Padi pada Lahan Sub Optimal, 2017

\begin{tabular}{|c|c|c|c|}
\hline No. & $\begin{array}{c}\text { Tingkat Pendidikan } \\
\text { (tahun) }\end{array}$ & $\begin{array}{l}\text { Jumlah } \\
\text { (Petani) }\end{array}$ & $\begin{array}{c}\text { Persentase } \\
(\%) \\
\end{array}$ \\
\hline 1. & $\leq 6$ & 45 & 56,25 \\
\hline 2. & $7-9$ & 16 & 20,00 \\
\hline 3. & $10-12$ & 18 & 22,50 \\
\hline \multirow[t]{2}{*}{4.} & $\geq 13$ & 1 & 1,25 \\
\hline & Jumlah & 80 & 100,00 \\
\hline
\end{tabular}

Jumlah anggota rumah tangga petani pada setiap keluarga berbeda-beda jumlahnya. Hal ini akan berpengaruh terhadap tingkat pendapatan dan alokasi pendapatannya. Karena semakin banyak jumlah anggota keluarga akan mendorong keluarga untuk mencari sumber pendapatan yang lebih banyak. Hal ini sependapat dengan Budiartiningsih et al (2010), bahwa semakin banyak anggota keluarga mendorong keluarga untuk mencari penambahan pendapatan rumah tangga secara informal untuk memenuhi kebutuhan yang semakin banyak pula. Karakteristik jumlah anggota keluarga petani pada lahan sub optimal di lokasi penelitian diuraikan pada Tabel 3. 
Tabel 3

Karaktersitik Jumlah Anggota Keluarga Petani Padi pada Lahan Sub Optimal, 2017

\begin{tabular}{|c|c|c|c|}
\hline No. & $\begin{array}{c}\text { Jumlah Anggota Keluarga } \\
\text { (jiwa) }\end{array}$ & $\begin{array}{l}\text { Jumlah } \\
\text { (petani) }\end{array}$ & $\begin{array}{c}\text { Persentase } \\
(\%)\end{array}$ \\
\hline 1. & $\leq 2$ & 8 & 10,00 \\
\hline 2. & $3-5$ & 59 & 73,75 \\
\hline \multirow[t]{2}{*}{3.} & $\geq 6$ & 13 & 16,25 \\
\hline & Jumlah & 80 & 100,00 \\
\hline
\end{tabular}

Data yang disajikan pada Tabel 3 diketahui bahwa jumlah petani yang memiliki anggota keluarga yang melebihi dari enam orang sebanyak 13 petani (16,25\%). Banyaknya anggota keluarga ini, karena umumnya dalam setiap rumah tangga petani terdapat tambahan anggota di luar keluarga inti seperti orang tua atau adanya lebih dari satu kepala keluarga.

Pengalaman menjadi peranan yang mempengaruhi pengetahuan dan keterampilan dalam kegiatan usahatani padi. Karena teknologi usahatani selalu mengalami perubahan seiring waktu berjalan. Bakhri dan Sudaryono (2016) melaporkan bahwa pengalaman petani berpengaruh yang signifikan terhadap produktivitas padi. Semakin bertambah pengalaman petani, maka akan meningkatkan produktivitas padi yang lebih tinggi. Namun Coelli and Battese (1998) berpendapat lain, bahwa walaupun petani memiliki pengalaman panjang dalam berusahatani untuk komoditas pertanian, namun petani tidak selalu dapat mencapai tingkat efisiensi dan produktivitas yang diharapkan, walaupun mempergunakan paket teknologi yang sama dan di lahan yang sama sekalipun keragaman selalu muncul. Hal ini disebabkan oleh faktor, baik yang dapat dikendalikan (internal) maupun yang tidak dapat dikendalikan atau eksternal. Tabel 4 menyajikan data terkait karakteristik pengalaman petani berusahatani pada lahan sub optimal di lokasi penelitian.

Tabel 4

Karaktersitik Pengalaman Petani Padi pada Lahan Sub Optimal, 2017

\begin{tabular}{cccc}
\hline No & $\begin{array}{c}\text { Pengalaman Berusahatani } \\
\text { (tahun) }\end{array}$ & $\begin{array}{c}\text { Jumlah } \\
\text { (petani) }\end{array}$ & $\begin{array}{c}\text { Persentase } \\
\text { (\%) }\end{array}$ \\
\hline 1. & $\leq 5$ & 14 & 17,50 \\
2. & $6-15$ & 29 & 36,25 \\
3. & $16-25$ & 22 & 27,50 \\
4. & $26-35$ & 10 & 12,50 \\
5. & $\geq 36$ & 5 & 6,25 \\
\hline & & $\mathbf{8 0}$ & $\mathbf{1 0 0 , 0 0}$ \\
\hline
\end{tabular}

Lahan juga sebagai faktor untuk menentukan produktivitas pertanian, demikian juga untuk menentukan jumlah produksi padi. Data yang disajikan pada Tabel 5 menunjukkan bahwa kelompok pemilikan lahan terbesar oleh petani di lokasi penelitian adalah pemilikan luas yang lebih dari 1 ha sebanyak 34 petani $(32,50 \%)$ dan pemilikan lahan seluas $0,76-1$ ha sebanyak 22 petani 
$(27,50 \%)$, selebihnya penguasaan lahan yang kurang dari 1 ha. Manatar et al (2017) melaporkan bahwa pengaruh status penguasaan lahan terhadap pendapatan petani, pendapatan yang paling tinggi adalah pendapatan petani penyewa. Pendapatan yang berbeda adalah pendapatan petani milik sendiri dengan pendapatan petani penyewa. Demikian juga Mufti dan Zargustin (2017) melaporkan bahwa dari segi luas lahan yang dimiliki petani, petani yang tergolong miskin sebahagian besar petani memiliki luas lahan yang relatif sempit berkisar antara 00,25 Ha. Kondisi ini tentu akan mempengaruhi produktivitas dari usahatani yang dilakukan. Oleh sebab itu petani lahan kering pada lokasi penelitian yang masuk kategori miskin mencapai 9 petani atau 11,25\%.

Tabel 5

Karaktersitik Penguasaan Lahan Petani Padi pada Lahan Sub Optimal, 2017

\begin{tabular}{|c|c|c|c|}
\hline No & $\begin{array}{c}\text { Penguasaan Lahan } \\
\text { (ha) }\end{array}$ & $\begin{array}{l}\text { Jumlah } \\
\text { (petani) }\end{array}$ & $\begin{array}{c}\text { Persentase } \\
\qquad(\%)\end{array}$ \\
\hline 1. & $\leq 0,25$ & 9 & 11,25 \\
\hline 2. & $0,26-0,5$ & 14 & 17,50 \\
\hline 3. & $0,51-0,75$ & 1 & 1,25 \\
\hline 4. & $0,76-1$ & 22 & 27,50 \\
\hline \multirow[t]{2}{*}{5.} & $\geq 1$ & 34 & 32,50 \\
\hline & Jumlah & 80 & 100,00 \\
\hline
\end{tabular}

\section{Keragaan Displai Padi Gogo}

Untuk mengubah persepsi petani padi lahan sub optimal dengan pengairan terbatas dapat dilakukan dengan penanaman padi, maka dilakukan displai padi gogo VUB hasil Badan Litbang Pertanian. Hasil pengamatan pertumbuhan dan produksi displai tanaman padi di lokasi penelitian secara rinci disajikan pada Tabel 6.

Hasil displai padi gogo lahan kering yang dilakukan sebagai keragaan pertumbuhan dan produksi padi varietas INPAGI 8, INPAGO 9, INPAGO 10 dan INPAGO 11. Sebagai pembanding adalah padi gogo varietas lokal. Pertumbuhan tinggi tanaman padi gogo pada masing-masing varietas adalah 126,96 cm, 118,95 $\mathrm{cm}, 118,40 \mathrm{~cm}, 135,75 \mathrm{~cm}$ dan 92,20 cm. Padi gogo varietas lokal mempunyai tinggi tanaman terpendek, sedangkan tertinggi adalah varietas INPAGO 11. Jumlah malai per rumpun akan berpengaruh terhadap produksi, hal tersebut apabila didukung dengan jumlah gabah/malai dan bobot gabah. Padi INPAGO 10 memiliki jumlah malai per rumpun terbanyak yaitu 21,15 malai/rumpun. Sedangkan ukuran malai terpanjang pada padi INPAGO 11 yaitu mencapai 27,70 $\mathrm{cm}$, dan juga jumlah biji per malai terbanyak juga yaitu 207,25 biji/malai. Hasil ubinan terbanyak pada dapi Inpago 10 mencapai 5,12 kg/6,25 m2, selanjutnya disetarakan luasan hektar produksinya $6,400 \mathrm{~kg} / \mathrm{ha}$. 
Tabel 6

Pertumbuhan dan Produksi Displai Tanaman Padi, 2017

\begin{tabular}{|c|c|c|c|c|c|c|}
\hline \multirow[b]{2}{*}{ No. } & \multirow[b]{2}{*}{ Parameter } & \multicolumn{5}{|c|}{ Varietas } \\
\hline & & $\begin{array}{c}\text { INPAGO } \\
8\end{array}$ & $\begin{array}{c}\text { INPAGO } \\
9\end{array}$ & $\begin{array}{c}\text { INPAGO } \\
10\end{array}$ & $\begin{array}{c}\text { INPAGO } \\
11\end{array}$ & Lokal \\
\hline 1. & $\begin{array}{l}\text { Tinggi Tanaman } \\
(\mathrm{cm})\end{array}$ & 126,96 & 118,95 & 118,40 & 135,73 & 92,20 \\
\hline 2. & $\begin{array}{l}\text { Jumlah } \\
\text { Malai/rumpun }\end{array}$ & 20,85 & 18,98 & 21,15 & 19,83 & 16,75 \\
\hline 3. & $\begin{array}{l}\text { Panjang Malai } \\
(\mathrm{cm})\end{array}$ & 24,31 & 24,30 & 24,15 & 27,70 & 24,20 \\
\hline 4. & $\begin{array}{l}\text { Jumlah Biji/malai } \\
\text { (biji/malai) }\end{array}$ & 109,35 & 108,58 & 107,96 & 207,25 & 104,90 \\
\hline 5. & $\begin{array}{l}\text { Bobot biji basah } \\
\text { (gr/malai) }\end{array}$ & 4,37 & 4,35 & 4,29 & 4,75 & 4,24 \\
\hline 6. & $\begin{array}{l}\text { Bobot } 2 \times 4 \mathrm{~m} 2 \\
(\mathrm{gr} / 8 \mathrm{~m} 2)\end{array}$ & 4,95 & 4,65 & 5,12 & 5,01 & 3,62 \\
\hline 7. & $\begin{array}{l}\text { Produksi } \\
(\mathrm{kg} / \mathrm{ha})\end{array}$ & 6,188 & 5,813 & 6.400 & 6,263 & 4.525 \\
\hline
\end{tabular}

Displai padi gogo VUB hasil Badan Litbang Pertanian sebagaimana temuan hasil penelitian ini diperkenalkan kepada petani, agar VUB tersebut lebih cepat dimanfaatkan oleh petani. Hal ini dimaksudkan agar petani dapat meningkatkan produksi usahataninya. Hal ini sejalan dengan pendapat Nazirah dan Damanik (2015) yang mengemukakan bahwa intensifikasi pertanian ditujukan untuk meningkatkan produksi, satu diantaranya adalah penggunaan VUB hasil Badan Litbang Pertanian. Hanya saja perlu dipertimbangkan bahwa petani dalam memilih varietas padi gogo bergantung pada selera dan respon petani terhadapnya. Hal ini sependapat dengan Bakhtiar et al (2013) menyatakan bahwa pada lokasi pengembangan padi lahan kering petani memilih varietas tertentu.

\section{Respon Petani Terhadap Padi Gogo VUB}

Selama pertumbuhan tanaman padi gogo VUB hasil Badan Litbang Pertanian hingga produksi dilakukan displai pada lahan BPP Kecamataan TogoTogo di Kabupaten Jeneponto. Selama masa itu pula petani melakukan pengamatan dan penilaian. Hasil respon petani terhadap pertumbuhan padi gogo VUB disajikaan pada Tabel 7.

Petani sekitar Kantor BPP Kecamatan Togo-Togo dalam kegiatan usahatani padi hanya mengandalkan irigasi dari Sungai Kelara yang mendapat bagian giliran sekitar bulan Februari. Kadang irigasi sebagai sumber air tersebut tidak mencukupi sampai panen, sehingga sering terjadi gagal panen. Sehingga dalam menghadapi kondisi seperti ini, maka dicarikan solusinya agar panen padi dapat 
dilakukan. Ruminta (2016), mengemukakan bahwa untuk mengurangi penurunan produksi tanaman padi karena perubahan kondisi iklim (ketersediaan air), maka rekomendasi yang menjadi pilihan yang strategis adalah penggunaan varietas padi unggul (produksi tinggi dan tahan terhadap kekeringan) bermutu, tahan kekeringan dan berumur genjah.

\section{Tabel 7}

Respon Petani Terhadap Padi Gogo VUB, 2017

\begin{tabular}{|c|c|c|}
\hline No. & $\begin{array}{l}\text { Aspek yang Diamati } \\
\text { pada Tanaman Padi } \\
\text { Gogo VUB }\end{array}$ & Respon Petani \\
\hline 1. & Waktu Penanaman & $\begin{array}{l}\text { Petani menganggap bahan benih padi hanya bisa } \\
\text { ditanam dalam kondisi lahan yang digenangi. }\end{array}$ \\
\hline 2. & $\begin{array}{l}\text { Pertumbuhan umur } \\
30 \text { HST }\end{array}$ & $\begin{array}{l}\text { Tanaman padi walaupun dalam kondisi lahan } \\
\text { kering, hanya mengandalkan tadah hujan dan } \\
\text { sekali dilakukan penyiraman dengan } \\
\text { pompanisasi, masih tetap tumbuh dengan baik. }\end{array}$ \\
\hline 3. & $\begin{array}{l}\text { Pertumbuhan } \\
\text { primordial }\end{array}$ & $\begin{array}{l}\text { Tanaman padi primordial pada umur kisaran } 45- \\
55 \text { HST }\end{array}$ \\
\hline 4. & Panen & $\begin{array}{l}\text { Tanaman padi yang ditanam tanpa genangan air } \\
\text { mulai dari tanam sampai panen, masih bisa } \\
\text { berproduksi. }\end{array}$ \\
\hline
\end{tabular}

Kekeringan pada lahan pertanaman padi dapat memberikan dampak yang bervariasi. Dampak kekeringan terhadap produksi padi dikelompokkan menjadi 3 kelas, yaitu kelas rendah, sedang dan tinggi. Di mana sawah yang kena dampak kekeringan kelas tinggi diasumsikan sebagai lahan sawah gagal panen (Iswari et al, 2016). Dalam mengatasi kekeringan langkah yang dapat ditempuh diantarnya; menggunakan varietas padi umur pendek dan melakukan curi "start" tanam (Muslim, 2013).

Kondisi tersebut, setelah memperhatikan bahwa benih padi bisa ditanam dengan sistem tugal dengan kondisi tanah lembab. Benih padi mampu tumbuh dan berproduksi dengan baik. Hal ini bila dilakukan untuk menyiasati kondisi iklim dan ketersediaan air irigasi, maka waktu tanam bisa dipercepat dan pola tanam bisa ditingkatkan. Indikator kelayakan teknologi mencakup tiga aspek, yaitu secara teknis mudah diterapkan, secara sosial dapat diterima dan secara ekonomi menguntungkan (Swantika, 2014).

\section{Pemahaman Petani Terhadap Padi Gogo Unggul}

Petani yang melakukan kegiatan usahatani memiliki pengetahuan terhadap usahatani yang ditekuninya. Pengetahuan itu tertuang dalam pemahamannya. Pemahaman petani terhadap padi gogo diuraikan secara rinci pada Tabel 8. 
Tabel 8

Pemahaman Petani Terhadap Padi Gogo, 2017

\begin{tabular}{cccc} 
No. & Uraian & $\begin{array}{c}\text { Jumlah } \\
\text { (Petani) }\end{array}$ & $\begin{array}{c}\text { Presentasi } \\
\text { (\%) }\end{array}$ \\
\hline 1. & Petani Tahu tentang padi gogo & 62 & 77,50 \\
2. & Petani mengusahakan padi & 80 & 100,00 \\
3. & Usahatani Padi mengalami peningkatan & 71 & 88,75 \\
4. & Petani menanam padi varietas unggul & 43 & 53,75 \\
5. & Petani Menanam padi benih berlabel & 41 & 51,25 \\
\hline
\end{tabular}

Pengetahuan petani dalam pemanfaatan lahan sawah tadah hujan dan sawah irigasi sederhana yang berkaitan dengan kegiatan usahataninya mempunyai nilai yang berbeda, bergantung pada pengetahuan dan pemahamannya. Tidak semua petani yang menjadi responden untuk mewakili petani sawah tersebut memiliki pengetahuan terhadap padi gogo. Jumlah petani yang tahu tentang padi gogo hanya 62 petani $(77,50 \%)$. Petani yang diwawancarai seratus persen mengusahakan tanaman padi, baik pada lahan sawah irigasi sederhana, sawah tadah hujan maupun lahan kering. Kegiatan usahatani padi selama beberapa tahun terakhir hanya 88,75 \% petani yang merasa bahwa usahatani padi mengalami peningkatan, sedangkan $21,25 \%$ petani tidak mengalami peningkatan.

Bahan tanam padi yang diusahakan oleh petani untuk memperoleh produktivitas diharapkan menggunakan varietas unggul bersertifikat. Petani padi yang menanam dengan varietas unggul hasil Badan Litbang Pertanian sudah mencapai 53,75\%. Sedangkan sebesar $46,25 \%$ petani tidak mengetahui jenis varietas unggul, karena benih diambil sendiri dari pertanaman padi musim sebelumnya atau dari milik tetangganya. Petani menggunakan benih padi varietas unggul bersertifikat yang diperoleh dari bantuan dari Pemerintah maupun membeli dari Toko Tani setempat baru mencapai 51,25\% petani.

\section{Rangking Preferensi Petani Terhadap Produksi Padi}

Sosialisasi teknologi produksi pada pemanfaatan varietas unggul hasil Badan Litbang Pertanian diharapkan dapat berdampak terhadap usahataninya maupun pelaksana usahatani. Rangking dan presentasi jumlah petani menilai pada hasil produksi padi yang diusahakannya disajikan pada Tabel 9.

Transfer teknologi produksi padi gogo dinilai oleh petani menghasilkan beberapa pendapat. Pendapat tertinggi adalah berpengaruh terhadap peningkatan keterampilan petani mencapai 70,00\% dan menempati rangking pertama. Apabila keterampilan petani meningkat, akan berdampak pada peningkatan penerapan teknologi produksi dilakukan dengan kesadaran yang tinggi. Kecocokan pemilihan peningkatan keterampilan ini signifikan. Rangking 
kedua adalah petani menilai peningkatan pendapatan petani mencapai $58,75 \%$. Sedangkan peningkatan produksi menduduki rangking yang ketiga. Dengan demikian petani sangat menyadari bahwa pemilihan sosialisasi terhadap teknologi prioritas utama adalah meningkatkan keterampilan yang akan berdampak pada peningkatan produksi dan mutu beras.

Tabel 9

Penilaian Petani Terhadap Hasil Padi yang Diusahakan, 2017

\begin{tabular}{clccc}
\hline No. & \multicolumn{1}{c}{ Hasil } & Rangking & $\begin{array}{c}\text { Jumlah } \\
\text { (petani) }\end{array}$ & $\begin{array}{c}\text { Persentase } \\
\text { (\%) }\end{array}$ \\
\hline 1. & Peningkatan produksi & 3 & 42 & 52,50 \\
2. & Peningkatan mutu beras & 4 & 34 & 42,50 \\
3. & Peningkatan pendapatan & 2 & 47 & 58,75 \\
4. & Peningkatan keterampilan & 1 & 56 & 70,00 \\
\hline & W & 0,4506 & & \\
\hline & X 2 hit & 72,09 & & \\
\hline
\end{tabular}

Penilaian terhadap tanaman padi yang diusahakan oleh petani dianggap akan meningkatkan produksi usahaninya berdasarkan pertumbuhan fisik dan produksi secara rinci diuraikan pada Tabel 10.

Tabel 10

Penilaian Petani Terhadap Peningkatan Produksi Padi, 2017

\begin{tabular}{llccc}
\hline No & \multicolumn{1}{c}{ Hasil } & Rangking & $\begin{array}{c}\text { Jumlah } \\
\text { (petani) }\end{array}$ & $\begin{array}{c}\text { Persentase } \\
\text { (\%) }\end{array}$ \\
\hline 1. & Pertumbuhan tanaman subur & 1 & 62 & 77,50 \\
2. & Jumlah anakannya banyak & 2 & 50 & 62,50 \\
3. & Jarak tanamnya rapat & 4 & 41 & 51,25 \\
4. & Jumlah malainya banyak & 5 & 35 & 43,75 \\
5. & Jumlah biji per malainya banyak & 3 & 44 & 55,00 \\
\hline & W $=0.4306$ & & & \\
\hline & X'hit & & & \\
\hline
\end{tabular}

Pertumbuhan tanaman padi bisa dijadikan parameter yang digunakan oleh petani untuk melakukan penilaiaan. Petani menilai bahwa tanaman padi yang diusahakan akan mengalami peningkatan produksi dapat dilihat dari kondisi pertanaman. Petani mempunyai kesepakatan atau kecocokan dalam menetapkan 
pertumbuhan tanaman yang subur sebagai parameter utama untuk menetapkan bahwa tanaman padi akan mengalami peningkatan produksi. Jumlah petani yang menilai bahwa tanaman padi yang subur akan memberikan peningkatan produksi sebesar 77,50\%.

Produksi padi dapat dipengaruhi oleh sifat-sifat yang dimiliki oleh tanaman itu sendiri. Adapun sifat-sifat tanaman padi yang dapat mempengaruhi produksi dan menjadi pilihan petani disajikan pada Tabel 11 .

Tabel 11

Penilaian Petani Terhadap Produksi Padi, 2017

\begin{tabular}{llccc}
\hline No. & \multicolumn{1}{c}{ Hasil } & Rangking & $\begin{array}{c}\text { Jumlah } \\
\text { (petani) }\end{array}$ & $\begin{array}{c}\text { Persentase } \\
\text { (\%) }\end{array}$ \\
\hline 1. & Varietas genjah & 1 & 37 & 46,25 \\
2. & Varietas tahan hama penyakit & 2 & 34 & 42,50 \\
3. & Varietas tahan terhadap kekeringan & 3 & 28 & 35,00 \\
\hline & W & 0,2723 & & \\
\hline & $\mathrm{X}^{2}$ hit & $=43,56$ & & \\
\hline
\end{tabular}

Varietas genjah merupakan sifat tanaman padi yang paling disukai oleh petani daalam menetapkan produksi. Pemilihan ini memiliki tingkat kecocokan 0,2723 dan signifikan menjadi pemilihan utama oleh petani. Petani yang memilih varietas genjah yang mempengaruhi produksi sebesar $46,25 \%$.

Penyediaan benih padi yang ditanam di lahan petani dibedakan atas benih berlabel dan tidak berlabel. Jumlah petani yang memilih benih padi yang berlabel maupun tidak berlabel jumlahnya sama, yaitu sebesar 91,25\%. Tingkat kecocokannya mencapai 1,332 dan signifikan. Pemilihan petani terhadap benih yang digunakan untuk usahatani padi secara lengkap disajikan pada Tabel 12.

Tabel 12

Penilaian Petani Terhadap Varietas Padi Unggul Berlabel, 2017

\begin{tabular}{|c|c|c|c|c|}
\hline No & Hasil & Rangking & $\begin{array}{l}\text { Jumlah } \\
\text { (petani) }\end{array}$ & $\begin{array}{c}\text { Persentase } \\
(\%)\end{array}$ \\
\hline 1. & Varietas unggul baru (VUB) berlabel & 1 & 73 & 91,25 \\
\hline 2. & Varietas lokal tanpa label & 1 & 73 & 91,25 \\
\hline & $=1,332$ & & & \\
\hline & $=106,6$ & & & \\
\hline & $=3,84$ & & & \\
\hline
\end{tabular}

Bentuk beras yang dihasilkan dari varietas yang diusahakan juga menjadi salah satu pertimbangan pilihan bagi petani untuk mengusahakannya. Pemilihan bentuk beras oleh petani memiliki kecocokan 0,7023. Hasil uji chi square 
menunjukan beda nyata. Kedua bentuk beras antara lonjong (hampir bulat) dan memanjang, semuanya menjadi pilihan yang paling disukai oleh petani. Jumlah petani yang menilai kedua jenis bentuk beras tersebut masing-masing sebesar $66,25 \%$. Penilaian terhadap bentuk beras yang dihasilkan dan menjadi pilihan petani disajikan pada Tabel 13.

Tabel 13

Penilaian Petani Terhadap Bentuk Beras, 2017

\begin{tabular}{lllcc}
\hline No. & \multicolumn{1}{c}{ Hasil } & Rangking & $\begin{array}{c}\text { Jumlah } \\
\text { (petani) }\end{array}$ & $\begin{array}{c}\text { Persentase } \\
\text { (\%) }\end{array}$ \\
\hline 1. & Lonjong (hampir bulat) & 1 & 53 & 66,25 \\
2. & Memanjang & 1 & 53 & 66,25 \\
\hline & $\mathrm{W}$ & & & \\
& $\mathrm{X}^{2}$ hit & 0,7023 & & \\
\hline
\end{tabular}

Cita rasa nasi merupakan salah satu penentu petani untuk memilih jenis varietas yang akan diusahakan, baik yang mengusahakan dengan tujuan pemenuhan konsumsi sendiri maupun untuk dijual. Keputusan petani akan mengusahakan tanaman padi berdasarkan rasa nasi dari beras mempunyai kecocokan 0,8801. Hasil uji chi square menunjukkan beda nyata. Petani memilih mengusahakan tanaman padi yang mempunyai rasa pera mencapai 95\%, karena sebagian besar hasil produksi usahataninya dikonsumsi sendiri dan hanya sebagaian yang dijual ke pedagang. Pemilihan kedua pada rasa nasi yang pulen dan terakhir, petani memilih tanam padi yang punya rasa nasi sedang. Hasil analisis disajikan pada Tabel 14.

Tabel 14

Penilaian Petani Terhadap Rasa Beras, 2017

\begin{tabular}{cllccc}
\hline No & & Hasil & Rangking & $\begin{array}{c}\text { Jumlah } \\
\text { (petani) }\end{array}$ & $\begin{array}{c}\text { Persentase } \\
(\%)\end{array}$ \\
\hline 1. & Pulen & & 2 & 52 & 65,00 \\
2. & Sedang & & 3 & 50 & 62,50 \\
3. & Pera & & 1 & 76 & 95,00 \\
\hline & W & $=0,8801$ & & & \\
\hline & $\mathrm{X}^{2}$ hit & $=140,82$ & & & \\
\hline
\end{tabular}

Warna beras juga menjadi penentu petani memilih jenis padi yang akan diusahakan di lahannya. Hasil analisis menunjukkan bahwa rangking pertama yang disukai oleh petani dalam menanam padi untuk menghasilkan beras yang 
berwarna putih mencapai 95,00\% petani. Nilai kecocokan mencapai 0,8123 dan berbeda nyata. Sedangkan rangking kedua petani memilih tanam padi beras hitam dan diikuti untuk menghasilkan beras merah. Hasil analisis secara lengkap disajikan pada Tabel 15.

Tabel 15

Penilaian Petani Terhadap Warna Beras, 2017

\begin{tabular}{clcccc}
\hline No & Hasil & Rangking & $\begin{array}{c}\text { Jumlah } \\
\text { (petani) }\end{array}$ & $\begin{array}{c}\text { Persentase } \\
(\mathbf{\%})\end{array}$ \\
\hline 1. & Hitam & & 2 & 60 & 75,00 \\
2. & Merah & & 3 & 35 & 43,75 \\
3. & Putih & & 1 & 76 & 95,00 \\
\hline & W & $=0,8123$ & & & \\
\hline & X $^{2}$ hit & $=129,96$ & & & \\
\hline & X $^{2}$ tab & $=5,99$ & & & \\
\hline
\end{tabular}

\section{Analisis Usahatani Padi Gogo}

Petani sebagai manajer dalam kegiatan usahataninya sehingga petani mempunyai kuasa penuh dalam menentukan komoditas yang diusahakannya. Dalam mengusahakan usahatani, petani mengharapkan produksi yang tinggi agar mampu memenuhi kebutuhan rumah tangganya, baik untuk konsumsi maupun pendapatan dari hasil penjualan produksi. Setidaknya, nilai biaya yang dikeluarkan oleh petani dapat ditutupi dengan nilai produksi yang dihasilkan. Untuk mengetahui analisis biaya usahatani padi gogo di lokasi penelitian, dapat dilihat pada Tabel 16.

Hasil analisis usahatani sebagaimana yang disajikan pada Tabel 16 menunjukkan bahwa komponen biaya usahatani padi gogo terdiri dari biaya sarana produksi, penyusutan peralatan dan biaya upah tenaga kerja. Biaya sarana produksi memerlukan hingga Rp 2.060.000/ha atau sebesar 27,79\% dari semua biaya usahatani. Biaya usahatani untuk sarana produksi terbesar adalah untuk pengadaan benih, yaitu sebesar Rp. 420.000/ha (5,67\%). Penyusutan peralatan pertanian yang digunakan dalam kegiatan usahatani padi gogo juga masuk sebagai komponen biaya, meskipun biaya itu tidak langsung dibayarkan, atau disebut sebagai biaya implisif. Besaran biayanya penyusutan peralatan sebesar Rp 350.000 (4,72\%). Sedangkan biaya tenaga kerja terdiri dari biaya eksplisif; yaitu pengolahan lahan, penanaman dan panen yang mencapai Rp $3032.500 /$ ha $(37,97 \%)$. Total biaya implisif mencapai Rp 5.352.500/ha (72,21\%).

Pengorbanan biaya usahatani oleh petani bertujuan untuk memperleh produksi padi gogo. Data hasil penelitian menunjukkan hasil panen yang diperoleh mencapai $3.425 \mathrm{~kg} /$ ha gabah kering giling. Harga gabah yang berlaku di pasaran mencapai Rp. 3.500/kg. Karena jenis beras yang dihasilkan adalah jenis beras merah, maka nilai penerimaan mencapai Rp 11.980.000/ha. Nilai penerimaan ini setelah dikurangi dengan biaya, maka diperoleh pendapatan secara implisif mencapai $\mathrm{Rp} 4.575 .500 /$ ha dan pendapatan secara eksplisif mencapai Rp 7.245.000/ha, dengan nilai R/C (implisif) 1,62 dan R/C (eksplisif) 2,53 . 
Tabel 16

Analisis Biaya, Penerimaan dan Pendapatan Usahatani Padi Lahan Kering di Sulawesi Selatan, 2017

\begin{tabular}{|c|c|c|c|c|c|}
\hline No. & Uraian & $\begin{array}{l}\text { Volume } \\
\text { (satuan) }\end{array}$ & $\begin{array}{l}\text { Harga } \\
\text { Satuan } \\
\text { (Rp/unit) }\end{array}$ & $\begin{array}{l}\text { Jumlah } \\
\text { (Rp) }\end{array}$ & $\begin{array}{c}\text { Persentase } \\
(\%)\end{array}$ \\
\hline \multirow[t]{10}{*}{1.} & Biaya Sarana Produksi & & & & \\
\hline & a. Benih & $70 \mathrm{~kg}$ & 6.000 & 420.000 & 5,67 \\
\hline & b. Pupuk Urea & $150 \mathrm{~kg}$ & 1.950 & 292.500 & 3,95 \\
\hline & c. Pupuk SP36 & $50 \mathrm{~kg}$ & 2.650 & 132.500 & 1,79 \\
\hline & d. Pupuk KCl & $100 \mathrm{~kg}$ & 2.450 & 245.000 & 3,31 \\
\hline & e. Pupuk Cair & $2 \mathrm{lt}$ & 30.000 & 60.000 & 0,81 \\
\hline & f. Herbisida & $3 \mathrm{lt}$ & 60.000 & 180.000 & 2,43 \\
\hline & g. Furadan & $1 \mathrm{~kg}$ & 80.000 & 80.000 & 1,08 \\
\hline & h. Fungisida & $2 \mathrm{lt}$ & 75.000 & 150.000 & 2,02 \\
\hline & i. Insektisida & $2 \mathrm{lt}$ & 75.000 & 150.000 & 2,02 \\
\hline 2 & Jumlah (1) & - & - & 2.060 .000 & 27,79 \\
\hline 3. & Penyusutan peralatan & 1 paket & 350.000 & 350.000 & 4,72 \\
\hline \multirow[t]{6}{*}{4.} & Biaya Tenaga Kerja & & & & \\
\hline & a. Pengolahan lahan & 1 ha pengolahan & 1.250 .000 & 1.250 .000 & 16,86 \\
\hline & b. Pembibitan & $4 \mathrm{OH}$ & 80.000 & 320.000 & 4,32 \\
\hline & c. Penanaman & 1 ha borongan & 750.000 & 750.000 & 10,1 \\
\hline & d. Pemeliharaan & $25 \mathrm{OH}$ & 80.000 & 2.000 .000 & 26,98 \\
\hline & e. Panen & $325 \mathrm{~kg}$ Bawon & 3.500 & 1.032 .500 & 13,93 \\
\hline 5. & Jumlah (2) & - & - & 5.352 .500 & 72,21 \\
\hline 6. & $\begin{array}{l}\text { Jumlah }(2+3+5) \\
\text { (implisit) }\end{array}$ & - & - & 7.987 .500 & 100,00 \\
\hline 7. & $\begin{array}{l}\text { Jumlah }(2+3+5) \\
\text { (eksplisit) }\end{array}$ & - & - & 4.742 .500 & - \\
\hline 8. & Produksi & 3.425 & - & - & - \\
\hline 9. & Penerimaan & 3.425 & 3.500 & 11.987 .500 & - \\
\hline 10. & Pendapatan (implisit) & - & - & 4.575 .500 & - \\
\hline 11. & Pendapatan (eksplisit) & - & - & 7.245 .000 & - \\
\hline 12. & $\mathrm{R} / \mathrm{C}$ (implisit) & - & - & 1,62 & - \\
\hline 13. & R/C (eksplisit) & - & - & 2,53 & - \\
\hline
\end{tabular}

Indikator kelayakan teknologi mencakup tiga aspek yaitu; secara teknis mudah diterapkan, secara sosial dapat diterima, dan secara ekonomi menguntungkan (Swantika, 2014). Edi dan Gusfarina (2013), mengemukakan bahwa bermacam-macam upaya dapat dilakukan guna mendatangkan keuntungan usahatani padi gogo, diantaranya adalah dengan menerapkan teknologi PTT padi gogo spesifik lokasi daerah aliran sungai memberikan keuntungan usahatani lebih baik dari pada teknologi petani.

\section{Kesimpulan}

Kegiatan usahatani padi gogo pada lahan sub optimal dilakukan oleh petani yang memiliki usia produktif. Penerapan teknologi usahatani padi pada lahan sub optimal dinilai belum intensif. Terkait dengan pemahaman petani 
terhadap padi gogo unggul dinilai belum optimal (77,50\%). Dari aspek preferensi petani dinilai signifikan terhadap petani padi gogo unggul. Hasil analisis usahatani menunjukkan usahatani padi gogo yang dikelola oleh petani memberikan pendapatan (implisif) sebesar $\mathrm{Rp} 4.575 .000 /$ ha dan pendapatan (eksplisif) sebesar Rp 7.245.000/ha dengan nilai R/C (implisif) 1,62 serta (eksplisif) 2,53.

\section{Daftar Pustaka}

Bakhri, F.R. dan L. Sudaryono, 2016. Faktor-faktor yang Mempengaruhi Produktivitas Usahatani antara Kecamatan Peterongan dan Kecamatan Megaluh Kabupaten Jombang. Jurnal Pendidikan Geografi Vol 3 No 3. 2016. Universitas Negeri Surabaya. Hal. 416 - 422.

Bakhtiar, Hasanuddin, dan T. Hidayat, 2013. Identifikasi Beberapa Varietas Unggul Padi Gogo di Aceh Besar. Jurnal Agrista Vol 17 No. 2 Tahun 2013. Fakultas Pertanian, Universitas Syiah Kuala, Banca Aceh. Hal. 49 - 54.

Budiartiningsih, R., Y. Maulida, dan Taryono, 2010. Faktor-Faktor yang mempengaruhi peningkatan pendapatan keluarga petani di Desa Kedaburapat, Kecamatan Rangsang Barat, Kabupaten Bengkalis. Jurnal Ekonomi Vol 18 No. 1 Maret 2010. Fakultas Ekonomi Universitas Riau. Hal. 79 - 93.

Christiani, C., Pratiwi T., dan B. Martono, 2012. Analisis Dampak Kepadatan Penduduk Terhadap Kualitas Hidup Masyarakat Provinsi Jawa Tengah. Jurnal Ilmiah Serat Acitya, Universitas 17 Agustus, Semarang. Hal. 102 - 114.

Coelli, T.J., D.S.P. Rao and G.E. Battese, 1998. Introduction to efficiency and productivity analysis. Boston: Kluwer Academic Publisher.

Dinas Pertanian Tanaman Pangan dan Hortikultura Propinsi Sulawesi Selatan (2014). Profil Dinas Pertanian Tanaman Pangan dan Hortikultura. Makassar.

Edi, S. dan D.S. Gusfarina, 2013. Kajian Pengelolaan Tanaman Terpadu dan Paket Petani Padi Gogo pada Lahan Kering di Provinsi Jambi. Jurnal Bioplantae. Fakultas Pertanian, Universitas Jambi Vol. 2 No 4, Oktober-Desember 2013. Hal. 161 -168.

Hernawan E. dan V. Meylani, 2016. Analisis Karakteristik Fisikokimia Beras Putih, Beras Merah dan Beras Hitam (Oryza sativa L., Oryza nivana, dan Oryza sativa L. indica). Jurnal Jesehatan Bakti Tunas Husada Vol 15 No. 1, Februari 2016. Fakultas Kesehatan, Universitas Siliwangi, Bandung. Hal. 79 - 91.

Iswari A.R., Hani'ah, A.L. Nugraha, 2016. Analisis Fluktuasi Produksi Padi Akibat Pengaruh Kekeringan di Kabupaten Demak. Jurnal Geodasi Vol. 5 No. 4 Oktober 2016. Universitas Dipanegara, Semarang. Hal. 233 - 242.

Larsito, S.,2005. Analisis keuntungan usaha tembakau rakyat dan efisiensi ekonomi relatif menurut skala luas lahan garapan. Program Studi Magister Ekonomi dan Studi Pembangunan. Program Pascasarjana. Undip. 106 hal.

Las, I. dan A. Mulyani, 2009. Sumberdaya Lahan Potensial Tersedia untuk Mendukung Ketahanan Pangan dan Energi. hlm. 64-74 Dalam Prosiding Semiloka Nasional Strategi Penanganan Krisis Sumber Daya Lahan untuk Mendukung Kedaulatan Pangan dan Energi. Fakultas Pertanian, IPB, Bogor. 
-------, M. Sarwani dan A, Mulyani, 2012. Laporan Akhir Kunjungan Kerja Tematik dan Penyusunan Model Percepatan Pengembangan Khusus Lahan Sub Optimal. Balai Besar Litbang Sumberdaya Lahan Pertanian, Bogor.

Manatar M.P., E.H. Loah dan J.R. Mandei, 2017. Pengaruh Status Penguasaan Lahan Terhadap Pendapatan Petani Padi di Desa Jumani Kecamatan Maesaan Kabupaten Minahasa Selatan. Jurnal Agri-SosioEkonomi Universitas Syam Ratulangi Vol 13 No 1 Januari 2017. Hal 55 - 64.

Mardani, T.M. Nur dan H. Satriawan, 2017. Analisis Usahatani Tanaman Pangan Jagung di Kecamatan Juli, Kabupaten Bireuen. Jurnal S. Pertanian Vol 1 No. 32017. Fakultas Pertanian, Universitas Almuslim. Hal. 203 - 212.

Mufti dan D. Zargustin. Penguasaan Lahan Usahatani Padi Sawah dan Hubungan dengan Tingkat Kemiskinan di Desa Padang Mutung, Kecamatan Kampar, Kabupaten Kampar. Jurnal Agribisnis Vol 19 No. 1 Juni 2017, Fakultas Pertanian Universitas Lancang Kuning. Hal 26 - 32.

Mulyani, A., S. Ritung dan Irsal Las, 2011. Potensi Dan Ketersediaan Sumber Daya Lahan Untuk Mendukung Ketahanan Pangan. Jurnal Litbang Pertanian, 30(2). Jakarta

- dan M. Sarwani, 2013. Karakteristik dan Potensi Lahan Sub Optimal untuk Pengembangan Pertanian Indonesia. Jurnal Sumberdaya Lahan Vol. 7 No. 1, 2013. Balai Besar Litbang Sumberdaya Lahan. Badan Litbang Pertanian. Hal. 47 - 55.

Muslim, C, 2013. Mitigasi Perubahan Iklim dalam Mempertahankan Produktivitas Tanah Padi Sawah (Studi Kasus di Kabupaten Indramayu). Jurnal Penelitian Pertanian Terapan Vol 13 No. 3, September 2013. Pusat Penelitian Sosial Ekonomi dan Kebijakan Pertanian, Bogor. Hal 211 - 222.

Nazirah, L. dan B.S.J. Damanik, 2015. Pertumbuhan dan Hasil Tiga Varietas Padi Gogo pada Perlakuan Pemupukan. Jurnal Floratek Vol 10 No. 1 Universitas Sumatera Utara, Hal 54 - 60.

Siegel, S., 1997. Statistik non Parametrik untuk ilmu sosial. Jakarta: PT. Gramedia Puataka Utama.

Sihotang F.R.H., L.A.M. Siregar dan L.Agustina P.P., 2014. Evaluasi Pertumbuhan dan Produksi Beberapa Varietas Padi Gogo (Oryza sativa L.) pada Beberapa Jarak Tanam yang berbeda. Jurnal Online Agroekoteknologi Vol 2 No. 2 Maret 2014. Fakultas Pertanian Universitas Sumatera Utara. Hal. 661 - 679.

Soekartawi. 2006. Agribisnis Teori dan Aplikasi. Jakarta: Rajawali Press.

Susanti D., N.H. Lestiana dan T. Widayat, 2016. Pengaruh Umur, Tingkat Pendidikan dan Luas Lahan Terhadap Hasil Produksi Tanaman Sembung. Jurnal Tumbuhan Obat Indonesia Vol 9 No. 2 2016. Balai Besar Penelitian dan Pengembangan Tanaman Obat dan Obat Tradisional.

Sunjaya, P. dan Y. Haryati. 2018. Kajian Produktivitas dan Respon Petani Terhadap Padi Varietas Unggul Baru di Kecamatan Parung Kuda dan Cicantayan Kabupaten Sukabumi. Jurnal Pengkajian Teknologi Pertanian Vol 21 No, 1, 2018. BBP2TP, Badan Litbang Pertanian, Kementerian Pertanian. 
Swastika, D.K.S, 2004. Beberapa Teknis Analisis dalam Penelitian dan Pengkajian Teknologi Pertanian. Jurnal Pengkajian dan Pengembangan Teknologi Pertanian Vol. 7 No. 1, Puslitbang Sosial Ekonomi Pertanian, Bogor.

Ruminta, 2016. Analisis Penurunan Produksi Tanaman Padi Akibat Perubahan Iklim di Kabupaten Bandung. Jurnal Kultivasi Vol 15 No. 1, Maret 2016. Departemen Budidaya Pertamian, Universitas Padjadjaran. Hal. 37 - 45. 